\title{
Resiliensi Pendidikan Diniyah dalam Menghadapi Covid-19 selama Bulan Ramadhan 2021
}

\author{
Jalaluddin \\ Universitas Islam Negeri Sunan Kalijaga Yogyakarta \\ jalaluddin.uinsuka@gmail.com
}

\begin{abstract}
Diniyah education has been implemented by all educational institutions in Indonesia, starting from the lowest level, namely SD/MI to SMA/MA. Initially this diniyah education was implemented in Islamic boarding schools during the month of Ramadan. The aim is to foster morals, character, and strengthen worship for students during the month of Ramadan. The purpose of this study was to identify the role of diniyah education carried out in the world of education during the Covid-19 pandemic. This research method is a literature study method with a qualitative approach. The results showed that the role of diniyah education can be measured through 4 things, namely increasing student religiosity, developing sustainable education and in accordance with the development of the times, being patient with calamities, and increasing husnuzon attitudes in students.
\end{abstract}

Keywords: Covid-19, Diniyah, Education, Ramadan, Resilience.

\begin{abstract}
Abstrak
Pendidikan Diniyah telah dilaksanakan oleh seluruh instansi pendidikan di Indonesia, mulai dari tingkatan paling bawah yaitu SD/MI sampai SMA/MA. Pada awalnya pendidikan diniyah ini diimplementasikan pada pendidikan pesantren kilat selama bulan Ramadhan. Tujuannya adalah untuk pembinaan akhlak, budi pekerti, dan penguatan ibadah bagi siswa selama bulan Ramadhan. Tujuan penelitian ini adalah untuk mengindentifikasi peran pendidikan diniyah yang dilaksanakan dalam dunia pendidikan selama masa pandemi Covid-19 ini. Metode penelitian ini dengan metode studi literatur dengan pendekatan kualitatif. Hasil penelitian menunjukkan bahwa peran pendidikan diniyah dapat diukur melalui 4 hal, yaitu peningkatan religiusitas siswa, pengembangan pendidikan berkelanjutan dan sesuai dengan perkembangan zaman, bersabar akan musibah, dan meningkatkan sikap husnuzon pada diri siswa.
\end{abstract}

Kata kunci: Covid-19, Diniyah, Pendidikan, Ramadhan, Resiliensi. 


\section{A. Pendahuluan}

Pandemi Covid-19 telah mewabah semenjak tahun 2019 dan awal 2020 Covid-19 mulai memasuki Indonesia (Virus Corona Masuk Indonesia, Kenali Gejala Dan Penyebabnya, n.d.). Dampak dari covid-19 begitu terasa hingga berpengaruh kepada penutupan sektor pendidikan dan melakukan pembelajaran jarak jauh atau daring sebagai langkah bijak yang harus dilakukan agar penyebaran Covd-19 tidak meluas (GTK, n.d.).

Status korban terpaparnya covid-19 di Indonesia masih tergolong sangat tinggi, meskipun berbagai upaya telah dilakukan hingga melakukan vaksinasi secara masal. Hingga saat ini pandemi covid-19 masih juga mempengaruhi setiap sektor kehidupan. Dalam bidang pendidikan meskipun sudah ada beberapa instansi yang telah mencoba melakukan proses belajar mengajar secara tatap muka, namun tidak tutup kemungkinan kebijakan tersebut dapat berubah sewaktu-waktu. Sekolah yang juga menerapkan proses belajar tatap muka juga tidak dapat terlepas dari aturan ketat dalam menjaga protokol kesehatan (Media, 2021).

Upaya dalam menekan penyebaran Pandemi Covid-19 telah dilakukan dengan sangat ketat oleh pemerintah, hal ini dapat dilihat dari aturan-aturan yang telah di keluarkan. Namun terlepas dari aturan-aturan, pemerintah juga harus mampu membangun psikologis masyarakat yang kuat yang mampu beresiliensi dengan baik. Sebagaimana diketahui bahwa Resiliensi pada manusia terutama pada saat pandemi covid-19 dapat membantu seseorang tetap aman, baik dan efektif (Pragholapati \& Indonesia, n.d.). Salah satu di antara beberapa faktor yang dapat meningkatkan resiliensi adalah peningkatan nilai religiusitas pada setiap individu, karena semakin tinggi nilai religiusitas seseorang maka akan semakin tinggi reiliensinya (Ramadhan \& Hamidy, 2021, p. 7). Momentum yang sangat tepat terutama dalam bidang pendidikan adalah dengan memanfaatkan bulan suci Ramadhan untuk memperkuat spiritualitas peserta didik melalui pendidikan Dinul Islam. 
Aceh sebagai provinsi yang menerapkan syariat Islam lebih memfokuskan pembelajaran selama bulan suci ramadhan kepada pendidikan diniyah (Ramadhan Sekolah di Aceh Fokus ke Pendidikan Diniyah, 2013). Materi belajar Diniyah lebih memfokuskan pada pembelajaran terhadap Al-Quran, Hadis serta materi keislaman lainnya. Pendidikan diniyah ini diharapkan agar mampu membentuk akhlak dan karakter peserta didik menjadi lebih baik, pada masa pandemi covid-19 ini pendidikan diniyah dalam bulan suci ramadhan menjadi sangat baik dilaksanakan terutama untuk meningkatkan religiositas peserta didik, dan nantinya akan memiliki resiliensi yang bagus terutama dalam menghadapi covid-19.

\section{B. Metode}

Penelitian ini menggunakan pendekatan kualitatif dengan studi literatur (Moleong, 2017). Penelitian kualitatif menjelaskan dan menganalisis fenomena, peristiwa, dinamika sosial, sikap kepercayaan, dan persepsi seseorang atau kelompok terhadap sesuatu. Studi kepustakaan dilakukan dengan mengumpulkan data dari berbagai buku, majalah dan sumber lainnya dan mampu mengolah data dengan tahapan-tahapan penelitian kepustakaan (Mestika, 2008).

Sumber data penelitian ini adalah Al-Quran yang ditambahkan penjelasan dari buku, jurnal, dan literatur lain. Adapun tahapan yang dilakukan dalam analisis data adalah dengan mengumpulkan data, reduksi data, display data, dan penarikan kesimpulan.

\section{Hasil dan Pembahasan}

\section{Pengaruh Religiusitas terhadap Resiliensi}

Resiliensi adalah kemampuan manusia untuk bertahan dalam berbagai kondisi yang tidak menguntungkan, atau bisa dikatakan sebagai kondisi terpuruk bagi individu yang meliputi rasa tertekan, sengsara bahkan traumatis (Saputra, 2020, p. 58). Menurut Reivich dan Shate resiliensi di 
artikan sebagai kapasitas seseorang untuk merespon terhadap sebuah peristiwa yang menyengsarakan (Ulfah et al., 2018, p. 121).

Resiliensi juga dapat didefinisikan sebagai kemampuan koping seseorang terhadap stressor atau kemampuan bertahan dari pengalaman emosional yang negatif (Hendriani, 2018, p. 22). Definisi lebih lengkap dapat kita lihat dari apa yang dipaparkan oleh Wiwin Hendriani yang mengatakan bahwa resiliensi merupakan sebuah proses dinamis yang melibatkan berbagai macam faktor seperti faktor dari dalam individu sendiri dan faktor sosial maupun lingkungan, yang kemudian menjadikan individu mampu bangkit dari pengalaman emosional negatif saat menghadapi kesulitan yang menekan atau hambatan yang signifikan (Hendriani, 2018, p. 24). Gambaran ini menunjukkan bahwa resiliensi tidak hanya bersumber dari diri individu melainkan juga dipengaruhi oleh lingkungan.

Pada dasarnya para ahli berbeda pendapat dalam menjelaskan resiliensi, sehingga dalam pendefinisian resiliensi para sering dibedakan menjadi dua kata yang berbeda namun dalam bahasa Indonesia sering di artikan sama. Perbedaan tersebut terlihat definisi yang diberikan kepada Resiliency lebih mengambarkan peran dominan kualitas internal individu dalam memunculkan adaptasi positif terhadap kesulitan. Sedangkan kata Resilience mengambarkan resiliensi yang lebih dinamis yaitu melibatkan beberapa faktor yang mempengaruhinya (Hendriani, 2018, p. 26).

Jika dilihat dari definisi di atas maka ada beberapa faktor yang mampu membentuk resiliensi, di antaranya yaitu: Pertama faktor internal yaitu kemampuan yang dimiliki oleh individu sendiri dalam beresiliensi seperti adanya kepercayaan diri, sikap optimis dan memiliki kualitas diri yang baik. Kedua faktor eksternal yaitu seperti dukungan lingkungan sekitar, dalam hal ini keluarga dan lingkungan sosial sangat berperan dalam memberikan support. Yang terakhir adalah problem solving yaitu kemampuan individu sendiri dalam menyelesaikan masalahnya (Wahidah, 2020, pp. 107-108). 
Faktor terakhir menurut penulis sendiri lebih kepada faktor internal individu, namun tidak terlepas juga dipengaruhi oleh faktor eksternal.

Jika dilihat dari sisi faktor eksternal manusia tidak dapat terlepas dari sebuah produk yang dipengaruhi oleh lingkungan, baik itu lingkungan keluarga, teman, sekolah, masyarakat dan sosial lainnya. Lingkungan ini membentuk manusia melalui proses pembelajaran atau pendidikan. Jika dilihat dalam konteks pendidikan agama maka sasaran dari pendidikan agama adalah aspek religiusitas, seperti beberapa penelitian oleh Firman Mansir tentang urgensi pemebelajaran Fiqh dalam meningkatkan religiositas siswa madrasah (Mansir, 2020). Upaya guru PAI dan akidah akhlak dalam meningkatkan religiusitas peserta didik (Aslamiyah \& Fitriyah, 2018)(HAJIJA, 2020). Strategi lain dalam meningkatkan religiusitas juga dapat dilakukan dengan pendidikan yang diberikan secara non formal seperti pembinaan (Islamiyah, 2020) dakwah (Ocha, 2021) dan melalui bimbingan rohani (SITI, 2021).

Tingkat religiusitas yang ada pada manusia juga nyatanya mempengaruhi kemampuan individu dalam beresiliensi, sebagaimana penelitian yang dilakukan oleh yoga ahmad ramadhan dan anwaril hamidy menunjukkan bahwa religusitas memiliki pengaruh terhadap masyarakat samarinda dalam menghadapi pandemi (Ramadhan \& Hamidy, 2021).

Pendidikan diniah yang merupakan pendidikan bernuasa keagamaan tentu memiliki sasaran dan target peningkatan religiusitas peserta didik, sama secara otomatis pengaruh pendidikan diniah adalah untuk menciptakan individu yang religius dan religiusitas dapat meningkatkan resiliensi.

\section{Peran Pendidikan Diniah dalam Meningkatkan Resiliensi}

Pendidikan merupakan upaya menarik sesuatu dalam diri manusia melalui pengalaman-pengalaman belajar dengan terprogram baik dalam bentuk formal, nonformal dan informal yang dilaksanakan di sekolah, dengan 
tujuan untuk mengoptimalisasikan kemampuan individu agar dapat memainkan peranan hidup secara tepat (Triwiyanto, 2014, pp. 23-24).

Darmaningtyas mengatakan bahwa pendidikan membutuhkan sebuah usaha sadar yang dilakukan secara sistematis (Ngainun \& Sauqi, 2008, p. 29). Adapun optimalisasi yang dilakukan pada individu menyangkut pada aspek daya pikir (Intelektual) maupun emosional yakni bagaimana individu berhubungan dengan orang lain (Sagala, 2013, p. 38), sedangkan Diniah berasal dari kata Ad-Din yang berarti agama sedangkan kata Diniah dalam kamus besar bahasa Indonesia diartikan sebagai hal yang bersifat keagamaan (Arti Kata Diniah - Kamus Besar Bahasa Indonesia (KBBI) Online, n.d.).

Sehingga pada dasarnya dapat di definisikan bahwa pendidikan diniah merupakan sebuah usaha sadar yang dilakukan oleh pengajar untuk mengoptimalkan yang di ajar terhadap segala sesuatu yang berkaitan dengan perilaku keagamaan. Dalam praktiknya istilah Diniah kerap di artikan sebagai sebuah jalur pendidikan non formal yang berada di bawah kementerian agama (2014, p. 7) dan biasanya sebutan lengkapnya adalah Madrasah Diniah. Madrasah diniah ini sering di kelompokkan kedalam tiga tingkatan, yatitu Awaliah, Wusta dan 'Ulya (Putra Daulay, 2001, pp. 61-62).

Dalam bulan suci ramadhan pelaksanaan pendidikan diniah kerap dilakukan di pagi hari selama bulan ramadhan, meskipun demikian pendidikan diniah sudah menjadi kurikulum tambahan dalam pendidikan di Aceh selama ini. Pada hari biasa pemberian materi dilakukan sore hari yakni setelah selesai sekolah formal, sedangkan selama ramadhan materi diniah diberikan pagi hari (Ramadhan Sekolah di Aceh Fokus ke Pendidikan Diniyah, 2013).

Kondisi Pandemi Covid-19 mengharuskan setiap kegiatan harus berfokus pada upaya mencegah penyebaran virus, pendidikan diniah yang dilakukan pada bulan ramdhan ini dapat menjadi kesempatan yang baik untuk meningkatkan resiliensi peserta didik melalui nilai-nilai keagamaan. Hal ini 
baik untuk dilakukan mengingat bahwa religiusitas mampu meningkatkan resiliensi (Ramadhan \& HamiDY, 2021, p. 7).

Materi yang dapat di gunakan dalam pembelajar diniah dalam rangka meningkatkan resiliensi lebih kepada materi tetang bagaimana sikap dan cara agama dalam menghadapi musibah, terutama musibah yang disebabkan oleh pandemi ini.

\section{Musibah dan Kesabaran}

Musibah yang terjadi di dunia ini tidak luput dari kuasa Allah SWT, sebagaimana Firmannya dalam Al-Quran Surat Al-Baqarah ayat 155, Allah berfirman, "Dan sesungguhnya Kami memberikan cobaan kepada kalian, dengan sedikit ketakutan, kelaparan, kekurangan harta, jiwa, dan buah-buahan. Dan berikanlah berita gembira kepada orang-orang yang sabar." Dalam menyikapi hal ini Allah SWT secara tegas memberikan solusi diantara cara menghadapi berbagai musibah ini.

Musibah dalam Islam terdapat beberapa macam tujuan Pertama musibah adalah Azab Allah SWT. Biasanya musibah ini ditimpakan kepada orang yang tidak mau berikan kepada Allah atau disebabkan karena berbuat maksiat kepada Allah SWT. Kedua musibah yang merupakan ujian. Musibah jenis ini biasanya menimpa orang-orang yang sudah berbuat sesuai dengan ketentuan Allah dan menjauhi segala larangannya, atau bahasa lain diberikan kepada orang-orang yang saleh sebagai ujian terhadap kesalehannya tersebut. Ketiga musibah sebagai konsekuensi, dimana setiap apa yang dikerjakan memiliki dampak terhadap kehidupan (Awaliah \& Alif, 2019, pp. 75-78).

Segala bentuk musibah yang diturunkan oleh Allah SWT kepada manusia tentu memiliki hikmah dibaliknya, terkadang manusia sendiri belum mampu sampai pada tahap penafsiran yang dapat memahami hikmahnya. Segala musibah dan ujian adalah sebagai jalan Allah menunjukkan dan mengangkat derajat hamba-Nya yang mampu bersabar terhadap musibah yang diberikan. Oleh sebab itu setiap Allah meberitakan musibah dalam 
Firman-Nya selalu di ikuti oleh anjuran atau berita gembira bagi mereka yang sabar.

Materi yang demikian tentu perlu untuk diberikan dalam muatan pendidikan diniah yang dilaksanakan dalam bulan ramadhan. Materi ini nantinya akan mampu menyadarkan kembali hikmah-hikmah yang di dapati dari musibah pandemi covid-19 ini, sehingga peserta didik dapat dilatih untuk lebih luwes, memiliki sikap sabar dalam menghadapi pandemi dan mampu untuk tetap berikhtiar di jalan Allah dalam rangka menanggulangi pandemi covid-19.

\section{Husnuzan}

Di samping adanya materi sebagai upaya menyadarkan individu bahwa segala sesuatu datangnya dari Allah dan semua akan memiliki hikmah dengan cara bersabar terhadap segala musibah. Maka sikap husnuzan juga harus di bangun dalam kesadaran perserta didik. Husnuzan adalah sikap berperasangka baik, berprasangka baik kepada Allah, diri sendiri dan sesama manusia. Sabar dan sikap menerima kenyataan tidak dapat terlepas dari keharusan individu dalam berhusnuzan. Husnuzan sendiri adalah kamampuan individu untuk menggunakan rasionalnya dengan berfikir hikmah dibalik setiap kejadian. Anjuran ber husnuzan ini juga terdapat dalam salah satu Firman Allah SWT dalam Al-Quran surat Al-hujurat ayat 12:

"Wahai, orang-orang yang beriman! Jauhilah banyak dari prasangka. Sesungguhnya, sebagian prasangka itu dosa dan janganlah kamu mencari-cari kesalahan orang lain dan janganlah ada di antara kamu yang menggunjing sebagian yang lain. Apakah ada sebagian kamu yang suka memakan daging saudaranya yang sudah mati? Tentu kamu merasa jijik. Dan, bertakwalah kepada Allah, sesungguhnya Allah Maha Penerima Tobat Lagi Maha Penyayang."

Jika kita lihat dalam konteks Teori Rasional Emotif Terapi (RET) maka husnuzan dapat dikatakan sebagai kemampuan untuk berfikir yang rasional. Asumsi dasar terapi RET ini menyatakan bahwa manusia akan lebih efektif ketika mampu berfikir rasional dan sebaliknya (Habsy, 2018, p. 16). Dengan 
demikian ketika individu mampu berfikir yang positif akan mampu menghadirkan kebaikan dan kebahagiaan pada diri individu itu sendiri.

Berhusnuzan juga mampu menghindari manusia dari stres akibat di timpa sesuatu, dalam psikoanalisis di rasionalisasi sebuah kejadian juga termasuk dalam sebuah mekanisme pertahanan diri manusia, yaitu dengan cara mencari alasan pembenaran dari sebuah kejadian (Dachrud \& Soleman, 2018, pp. 33-34). Dengan adanya materi ini mampu menjadi penunjang materi sebelumnya dan keberhasilan pemberian materi ini dalam materi pendidikan diniah dengan benar diharapkan mampu menumbuhkan resiliensi yang baik pada setiap peserta didik sehingga mampu menghadapi pandemi covid-19.

\section{Kesimpulan}

Pendidikan diniah yang dilaksanakan pada setiap instansi pendidikan yang ada di Aceh memiliki kesempatan yang baik untuk meningkatkan resiliensi siswa melalui pendekatan keagamaan. Materi yang dapat diberikan juga bisa berupa pemahaman agama secara umum, materi tentang musibah dan kesabaran, serta materi husnuzan. Kesemua materi ini saling bersinergi untuk dapat merubah paradigma berfikir peserta didik. Dengan pelaksanaanya yang dilaksanakan secara sistematis maka seyogyanya mampu menumbuhkan atau meningkatkan resiliensi pada peserta didik terutama dalam menghadapi pandemi covid-19 ini.

\section{Daftar Pustaka}

Arti kata diniah-Kamus Besar Bahasa Indonesia (KBBI) Online. (n.d.). Retrieved May 3, 2021, from https://kbbi.web.id/diniah Aslamiyah, S. S., \& Fitriyah, A. (2018). Upaya Guru Pai Dalam Meningkatkan Religiusitas Peserta Didik. Akademika, 12(02), Article 02. https://doi.org/10.30736/adk.v12i02.179

Awaliah, L., \& Alif, M. (2019). Musibah dalam Perspektif Hadis. Holistic AlHadis, 5(2), 68-91.

Dachrud, M., \& Soleman, A. (2018). Memahami Pencitraan Politik Melalui Pendekatan Mekanisme Pertahanan Diri. Potret Pemikiran, 19(2). 
GTK, S. (n.d.). Kebijakan Kemendikbud di Masa Pandemi. Retrieved April 26, 2021, from http://gtk.kemdikbud.go.id/read-news/kebijakankemendikbud-di-masa-pandemi

Habsy, B. A. (2018). Konseling rasional emotif perilaku: Sebuah tinjauan filosofis. Indonesian Journal of Educational Counseling, 2(1), 13-30.

HAJIJA, H. (2020). Upaya Guru Aqidah Akhlak Dalam Meningkatkan Religiusitas Siswa Melalui Strategi Pakem Di Kelas Ii Sd 'Aisyiyah 1 Mataram [Undergraduate, Universitas Muhammadiyah Mataram]. http://repository.ummat.ac.id/1093/

Hendriani, W. (2018). Resiliensi Psikologis: Sebuah Pengantar. Kencana. Islamiyah, S. S. (2020). Pembinaan agama Islam dalam meningkatkan religiusitas narapidana di Pesantren At-Taubah Lembaga Pemasyarakatan Klas I Malang [Undergraduate, Universitas Islam Negeri Maulana Malik Ibrahim]. http://etheses.uinmalang.ac.id/23985/

Kemenag RI. (2014). Pedoman Penyelenggaraan Madrasah Diniyah Takmiliyah. Kemenag.

Mansir, F. (2020). Urgensi Pembelajaran Fiqih dalam Meningkatkan Religiusitas Siswa Madrasah: Pembelajaran Fiqih. AL-WIJDÁN: Journal of Islamic Education Studies, 5(2), 167-179.

Media, K. C. (2021, March 30). Kemendikbud: Aturan Lengkap Belajar Tatap Muka di Sekolah Halaman all. KOMPAS.com. https://www.kompas.com/edu/read/2021/03/30/141534871/keme ndikbud-aturan-lengkap-belajar-tatap-muka-di-sekolah

Mestika, Z. (2008). Metode Penelitian Kepustakaan. Jakarta: Yayasan Obor Indonesia.

Moleong, L. J. (2017). Metodologi Penelitian Kualitatif. Jakarta: Remaja Rosda Karya.

Ngainun, N., \& Sauqi, A. (2008). Pendidikan multikultural: Konsep dan aplikasi

(Cet. 1). Ar-Ruzz Media: Didistribusikan oleh Ar-Ruzz Media Group.

Ocha, S. (2021). Strategi Dakwah Rohis Dalam Meningkatkan Religiusitas Remaja Di Smk Yapena Bandar Lampung [Undergraduate, UIN RADEN INTAN LAMPUNG]. http://repository.radenintan.ac.id/13008/

Pragholapati, A., \& Indonesia, P. (n.d.). Resiliensi Pada Kondisi Wabah Covid19.

Putra Daulay, H. (2001). Historisitas dan Eksistensi Pesantren Sekolah dan Madrasah. Tiara Wacana.

Ramadhan Sekolah di Aceh Fokus ke Pendidikan Diniyah. (2013, July 15). Republika Online. https://republika.co.id/berita/pendidikan/eduaction/13/07/15/mpy y6v-ramadhan-sekolah-di-aceh-fokus-ke-pendidikan-diniyah

Ramadhan, Y. A., \& HamiDY, A. (2021). Resiliensi Masyarakat Samarinda dalam Menghadapi Pandemi Covid-19 dan Faktor-Faktornya. 1(1), 12.

Sagala, S. (2013). Etika \& Moralitas Pendidikan: Peluang dan Tantangan. Prenada Media. 
Saputra, T. A. (2020). Bentuk Kecemasan Dan Resiliensi Mahasiswa

Pascasarjana Aceh-Yogyakarta Dalam Menghadapi Pandemi Covid-19. 6(1), 55-61.

SITI, N. (2021). Bimbingan Rohani Islam Dalam Meningkatkan Religiusitas Santri Di Pondok Pesantren Al-Munir Al-Islamy Kecamatan Sukoharjo Kabupaten Pringsewu [Undergraduate, UIN RADEN INTAN LAMPUNG]. http://repository.radenintan.ac.id/12901/

Triwiyanto, T. (2014). Pengantar Pendidikan. Bumi Aksara.

Ulfah, E., Bakhtiar, B., \& Irma, H. T. (2018). Resiliensi Wanita Penderita Kanker Payudara Stadium Lanjut. Al-Qalb: Jurnal Psikologi Islam, 9(2), 119-129.

Virus Corona Masuk Indonesia, Kenali Gejala dan Penyebabnya. (n.d.). Retrieved April 26, 2021, from https://health.detik.com/beritadetikhealth/d-4921882/virus-corona-masuk-indonesia-kenali-gejaladan-penyebabnya

Wahidah, E. Y. (2020). Resiliensi Perspektif Al Quran. JURNAL ISLAM NUSANTARA, 2(1), 105-120. 
